\title{
Assessment of Regional Climate Models over Côte D'Ivoire and Analysis of Future Projections over West Africa
}

\author{
Kouakou Kouadio1,2, Abdourahamane Konare1, Adama Diawara1, Bernard Kouakou Dje ${ }^{3}$, \\ Vincent Olanrewaju Ajayi ${ }^{2}$, Arona Diedhiou ${ }^{4}$ \\ ${ }^{1}$ Laboratoire de Physique de l'Atmosphère et Mécanique de Fluide (LAPA-MF), Université Felix \\ Houphouët-Boigny, Abidjan, Côte d'Ivoire \\ ${ }^{2}$ WASCAL Graduate Research Program on West African Climate System (GRP-WACS), Federal University of \\ Technology Akure (FUTA), Akure, Nigeria \\ ${ }^{3}$ Société d'exploitation et développement Aéroportuaire et Météorologique, Abidjan, Côte d'Ivoire \\ ${ }^{4}$ LTHE-IRD, Université de Grenoble, Grenoble, France \\ Email: kk.kouadio@yahoo.fr
}

Received 19 January 2015; accepted 25 March 2015; published 31 March 2015

Copyright (C) 2015 by authors and Scientific Research Publishing Inc.

This work is licensed under the Creative Commons Attribution International License (CC BY). http://creativecommons.org/licenses/by/4.0/

(c) (i) Open Access

\section{Abstract}

The ability of six Regional Climate Models (RCMs) used in AMMA-ENSEMBLES project is assessed over six meteorological stations in Côte d'Ivoire. The ensemble mean of the models is also used for the prediction of climate change over West Africa. The study focused on two periods: the period 1995-2005, the present-day simulations, is used to evaluate the skills of the models over the

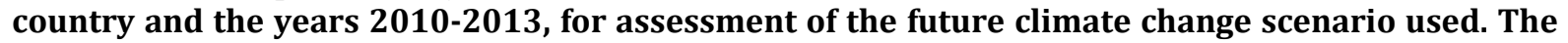
results show that the skills of the models vary from one station to another and from one season to another. None of the models considered, presents an excellent performance over the entire country and in all the seasons. Generally, the ensemble mean of all the models presents better results when compared with the observation. These results suggest that the choice of any model for study over the country may depend on the focus of interest: intensity or variability of the rain and also on area of interest. The projection for 2020-2040, future climate change over West Africa shows that the Sahel exhibits a tendency to be drier while wetter Guinean coast is observed.

\section{Keywords}

AMMA, Ensembles, West Africa Monsoon, Regional Climate Models, Precipitation 


\section{Introduction}

West African Monsoon is a coupled atmospheric, oceanic and land system. These coupled systems include mesoscale convective systems (MCSs); modulated by the westward moving African Easterly Waves (AEW), The Mid-tropospheric African Easterly Jet and Inter-hemispheric Tropical Easterly Jet. The monsoon is also strongly dependent on regional and global Sea Surface Temperature (SST) variations [1] [2]. Lamb [3] reports that the Atlantic SST anomaly influences the sub-Saharan summer rainfall. He further showed that there is negative SST anomaly during spring (April-May) and a positive one during the summer (June-September) which is associated with dry year and vice versa. Apart from SST anomaly many studies has related rainfall to other changes in surface conditions. For instance, many studies have been linked soil moisture to precipitation over West Africa [4]-[6]. It has a positive feedback with the precipitation and may influence the position of the storm system [7] [8]. The Inter-tropical Discontinuity (ITD) has been mostly pointed out for its influence on the rain distribution over this region mainly on the northward shift and the southward retreat of the WAM [9] [10].

Regional Climate Models (RCMs) have been used in acceptable manners to understand the West African Monsoon (WAM) at different spatial and temporal scales [11]-[18]. Recently, in the framework of the West African Monsoon Modeling and Evaluating (WAMME) project, [16] observed a relative difference between the simulations made at the Universities of Cocody (Côte d'Ivoire) and Abdou Moumouni (Niger) while executing an inter-comparison between five RCMs. This bias was attributed to the different kind of Sea Surface Temperatures (SST) used for the forcing of different WAM simulations. During The African Monsoon Multidisciplinary Analysis (AMMA) program, many efforts have been made for better understanding the WAM through a long-term collaboration to study the climatic and environmental feedback mechanisms involved in the African monsoon, and in some of its consequences on society and human health.

The major setback in the study of WAM is the availability of continuous and reliable datasets. The AMMAENSEMBLES project funded by the European Commission's 6th Framework Program is an opportunity to have deeper insight into the behavior of West African Monsoon system. This platform had already been used to undertake study over West Africa. For instance, [19] focusing in an interannual variability of rainfall over Sahel report that main of the models used provide a good estimation of the rainfall variability because of their skills in the representation of the WAM features. Other efforts have been done using data from similar project: The Coordinated Regional Downscaling Experiment (CORDEX) program recently established by the World Climate Research Program (WCRP). Among them, [20] assessed the ability of 10 Regional Climate Models (RCM) to replicates the observed features of WAM. They found out the capability of these models in the replication of temporal and spatial distribution of the precipitation and temperature over West Africa but with biases. These biases vary from one model to another. They also reported like [21] that using the ensemble mean of these models enhanced the representation of these features. This result was corroborated by the work of [22], focusing only on precipitation [16] [23]. More recently, [21], discovered significant differences firstly between the observation and the models and secondly among the RCMs themselves in term of daily rain amount, intensity, extremes and the duration of rainfall events inside the WAM. According to them, this underlined the problematic of the sweeping uncertainties in the simulation of daily precipitation features. These results reinforced the belief that precipitation is the most difficult parameter to simulate accurately in RCMs.

This study will assess the performance of six models used in the AMMA-ENSEMBLES project in their basic representation of rainfall. In analysis of the result, we will consider two time windows. The first one, 1990 to 2005 which is related to the historical and current period, and the short and second one is likely an opportunity to evaluate these models in the projection of the future. So that this result may indicate a degree of reliability in the use of the dataset in Côte d'Ivoire particularly and West Africa in general. Secondly we will also perform a projection over the period 2020-2040 taking 1990-2005 period as the reference.

\section{Domains, Data and Methods}

Under the AMMA-ENSEMBLES project, an ensemble of simulations [24] has been made over Africa domain. For these simulations, all of the RCMs are driven for the period 1990-2007 (first window) by the same lateral boundary conditions taken from the European Centre for Medium-Range Weather Forecasts reanalysis ERAinterim ([25] [26]). For the projection 2010-2013 (second window), the simulations have been done under the scenario A1B and the lateral boundary conditions are provided by ECHAM5-r3 or HadCM3Q0. The objective is to build an international coordinated framework for generating improved regional climate change projections 
worldwide. In this work, we will firstly assess the basic performance over Côte d'Ivoire of six models (METO-HC_HadRNM3 (HadRM), ICTP-REGCM3 (RegCM3), METNO-HIRHAM, SMHI-RCA (RCA), DMIHIRHAM5, KNMI-RACMO2 (RACMO)). Secondly we will make a projection over West Africa. All the simulations had been made over the same domain and havethe same horizontal resolution $\left(0.44^{\circ} \times 0.44^{\circ}, \sim 50 \mathrm{~km}\right)$. Simulation outputs are freely available from http://ensemblesrt3.dmi.dk/. Table 1 gives an overview of the RCMs configurations for these simulations [27].

Two time windows are considered in this work. The first time window was between 1990 and 2005, the lateral boundary was forced by ERA-interim data and while for second time slice (2010-2013), was forced by ECHAM5-r3 or HadCM3Q0 data (see Table 1). In the first windows, the ability of the models to reproduce the past and current rainfall pattern is assessed while the later one is to assess the performance of those models in the projection of the future scenarios. The models outputs are compared to six (6) weather stations data from the National Meteorology Office of Côte d'Ivoire. Non-availability of continuous dataset due to socio-economic crises in Côte d'Ivoire limited the studies to six meteorological stations, of Abidjan, Bondoukou, Daloa, Dimbokro, Gagnoa and Tabou have been used. This lack of data impresses to focus only in the southern climatic zone (Abidjan, Tabou) and the center climatic zone (Bondoukou, Dimbokro, Gagnoa and Daloa) part of the

Table 1. Summary of the different Regional Climate Models used in this work and their respective main physical schemes and latest references.

\begin{tabular}{|c|c|c|c|c|c|c|}
\hline & \multicolumn{6}{|c|}{ RCMs } \\
\hline & $\begin{array}{c}\text { ICTP-Reg } \\
\text { CM3 }\end{array}$ & DMI-HIRHAM5 & KNMI-RACMO & SMHI-RCA & $\begin{array}{c}\text { METO-HC_ } \\
\text { HadRM }\end{array}$ & METNO-HIRHAM \\
\hline $\begin{array}{l}\text { Institute running } \\
\text { the model }\end{array}$ & $\begin{array}{l}\text { International } \\
\text { Center for } \\
\text { Theoretical } \\
\text { Physics, Italy }\end{array}$ & $\begin{array}{c}\text { Danmarks, } \\
\text { Meteorologiskeinstitut, } \\
\text { Danmark }\end{array}$ & $\begin{array}{l}\text { Koninklijk } \\
\text { Nederlands } \\
\text { Meteorologisc } \\
\text { Instituut, } \\
\text { Netherlands }\end{array}$ & $\begin{array}{c}\text { Sveriges } \\
\text { Meteoro- } \\
\text { logiskaoch } \\
\text { Hydrologiska } \\
\text { institut, Sweden }\end{array}$ & $\begin{array}{c}\text { Met Office Hadley } \\
\text { Centre, } \\
\text { UK }\end{array}$ & $\begin{array}{c}\text { The } \\
\text { Norvegian } \\
\text { Meteorological } \\
\text { Institute, } \\
\text { Norway }\end{array}$ \\
\hline Projection & Mercator & Rotated Pole & Rotated Pole & Rotated Pole & Rotated Pole & $\begin{array}{c}\text { Geographical } \\
\text { latitude/longitude }\end{array}$ \\
\hline Resolution & $50 \mathrm{~km}$ & $0.44(50 \mathrm{~km})$ & $0.44(50 \mathrm{~km})$ & $0.44(50 \mathrm{~km})$ & $0.44(50 \mathrm{~km})$ & $0.44(50 \mathrm{~km})$ \\
\hline $\begin{array}{c}\text { Vertical } \\
\text { coordinates }\end{array}$ & Sigma/18 & Hybrid/ 31 & Hybrid/40 & Hybrid/40 & Hybrid/40 & $\begin{array}{c}\text { Pressure based } \\
\text { terrainfollowing } \\
\text { (hybrid coordinates) }\end{array}$ \\
\hline Advection & Eulerian & Semi-lagrangian & Semi-lagrangian & Semi-lagrangian & & $\begin{array}{l}\text { Semi-lagrangian } \\
\text { (semi-implicit) }\end{array}$ \\
\hline Time step (s) & 100 & 600 & 720 & 1200 & & 900 \\
\hline Convective scheme & [37] [38] & [39] [40] & [40] & [41] & [42] [43] & [39] [40] \\
\hline Radiation scheme & {$[44]$} & {$[45][46]$} & [47] & [48] [49] & {$[50]$} & {$[45][46]$} \\
\hline $\begin{array}{c}\text { Turbulent vertical } \\
\text { diffusion }\end{array}$ & [51] & {$[52]$} & $\begin{array}{l}\text { Eddy-diffusitivity } \\
\left(1^{\text {st }} \text { order K) mass }\right. \\
\text { flux approach }\end{array}$ & {$[53]$} & [54] & [55] \\
\hline $\begin{array}{l}\text { Cloud microphysics } \\
\text { scheme }\end{array}$ & {$[56]$} & [57] & [40] & {$[58]$} & [59] [60] & [57] \\
\hline Land surface & {$[61]$} & [62] & [63] & $\begin{array}{l}\text { RCA land } \\
\text { surface } \\
\text { model [64] }\end{array}$ & [65] & {$[66]$} \\
\hline $\begin{array}{l}\text { Driving GCM } \\
\text { current/for } \\
\text { projection }\end{array}$ & $\begin{array}{l}\text { ERA-interim } \\
\text { /ECHAM5-r3 }\end{array}$ & $\begin{array}{l}\text { ERA-interim } \\
\text { /ECHAM5-r3 }\end{array}$ & $\begin{array}{l}\text { ERA-interim } \\
\text { /ECHAM5-r3 }\end{array}$ & $\begin{array}{l}\text { ERA-interim } \\
\text { /HadCM3Q0 }\end{array}$ & $\begin{array}{l}\text { ERA-interim } \\
\text { /HadCM3Q0 }\end{array}$ & $\begin{array}{l}\text { ERA-interim } \\
\text { /HadCM3Q0 }\end{array}$ \\
\hline $\begin{array}{l}\text { Sea surface } \\
\text { temperature } \\
\text { (SST) type }\end{array}$ & $\begin{array}{c}\text { NOAA/weekl } \\
\text { y } \\
\text { Optimum } \\
\text { interpolated } \\
\text { SST }\end{array}$ & ERA-interim SST & ERA-interim SST & $\begin{array}{l}\text { ERA-interim } \\
\text { SST }\end{array}$ & ERA-interim SST & ERA-interim SST \\
\hline $\begin{array}{l}\text { Latest reference } \\
\text { and comments }\end{array}$ & [67] & {$[68]$} & $\begin{array}{c}\text { [69]; based on } \\
\text { ECMWF cycle } 3 \text { lrl } \\
\text { (ECMWF 2006) }\end{array}$ & {$[70]$} & [71] & [68] \\
\hline
\end{tabular}


country instead of the whole area as described in [28] [29]. In fact these works suggested three climatic zones (south, center, north) in Côte d'Ivoire which may be related to the vegetation cover; forest in the south, wooded savanna in the center and grassy savanna in the north. Figure 1 gives an overview of the climatic zone of Côte d'Ivoire adapted from [28] [29] and the location of the stations used over the country.

Taylor diagram is used as statistical tool in order to check how close are the model estimation to the observation [30], root mean square (RMS) is also used to test the deviation of model results from observations. The standard deviation (mm of rain) indicates the amplitude of variation. So that a simulation that is in good agreement with the observed will be located near the point marked "obs" (observation) on the x-axis. This simulation must have relative high correlation and low RSM errors (RMSE). It should have furthermore the correct standard deviation which will indicate that the pattern variation has the right amplitude. This work focuses specially on the monthly evolution, the seasonal cycle and also the estimation of the maximum of rain amount.

The regional analysis over West Africa is made with a special focus over three basins; the Volta, Senegal and Bandama basins. The Volta basin covers an area of $400,000 \mathrm{~km}^{2}$, stretches from $5^{\circ} 30^{\prime} \mathrm{N}$ in Ghana to $14^{\circ} 39^{\prime} \mathrm{N}$ in Mali and its widest stretch is from $5^{\circ} 30^{\prime} \mathrm{W}$ to $2^{\circ} \mathrm{E}$. It is spread over six West African countries (43\% in Burkina Faso, $42 \%$ in Ghana, and $15 \%$ in Togo, Benin, Côte d'Ivoire and Mali). The Volta basin is divided into two parts (north and south) according to the local climate. The Senegal basin covers around $300,000 \mathrm{~km}^{2}$. The Senegal River is 1800 kilometers long. This basin stretches from $8^{\circ} \mathrm{N}$ in Guinea to $14^{\circ} 39^{\prime} \mathrm{N}$ in Mauritania and its widest stretch is from $18^{\circ} \mathrm{W}$ to $5^{\circ} \mathrm{W}$. Its riparian countries are Guinea, Mali, Mauritania, and Senegal. The main part of the basin is located in the Sahelian and desert zone. The Bandama River is the longest river in Côte d'Ivoire with a length around 800 kilometers. In this study the term Bandama refers to all the Rivers (Bandama, Comoe, Sassandra and Cavally) in Côte d'Ivoire. Then we will have a general idea of the basins in the country.

In the following section the term ensemble refers to the average of the estimation of the different models used.

\section{Results and Discussion}

\subsection{Present-Day Simulation (1990-2005)}

\subsubsection{Monthly Evolution}

Figure 2 shows the Taylor diagram computed with the monthly rainfall for each station, each of the models is represented with alphabetical letter. Letter A represents the simulation made by RegCM3, letter B is for DMIHIRHAM, while C, D, E, F and G corresponds to HadRM, RACMO, METNO-HIRHAM, RCA and ensemble respectively while Obs on the $\mathrm{x}$-axis indicates the observation. Ensemble is the average of the six models used in this study. There are considerable discrepancies between the observation and the models output in general, and

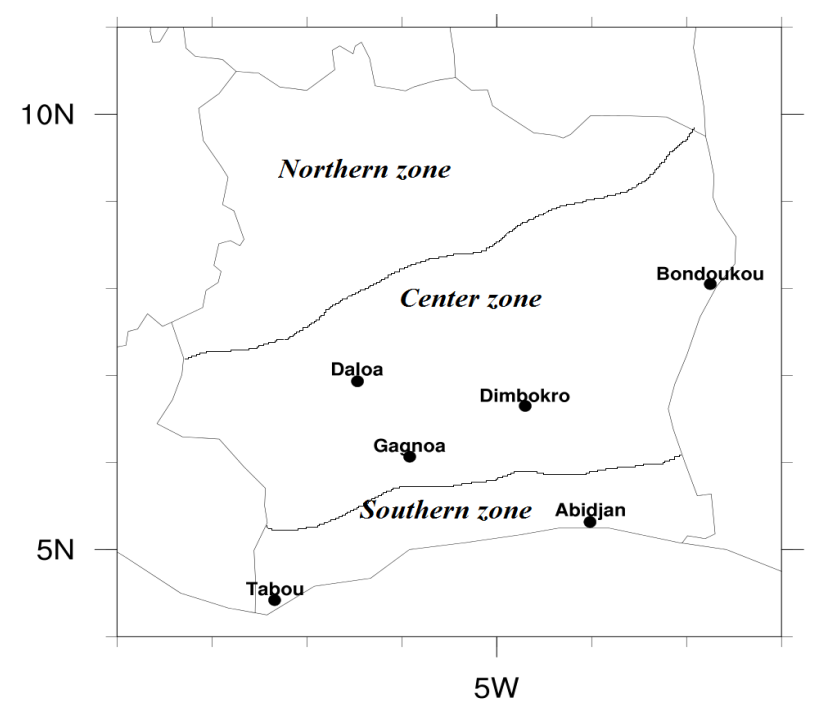

Figure 1. Climatic zone and geographical location of stations used over Côte d'Ivoire; adapted from [28] [29]. 

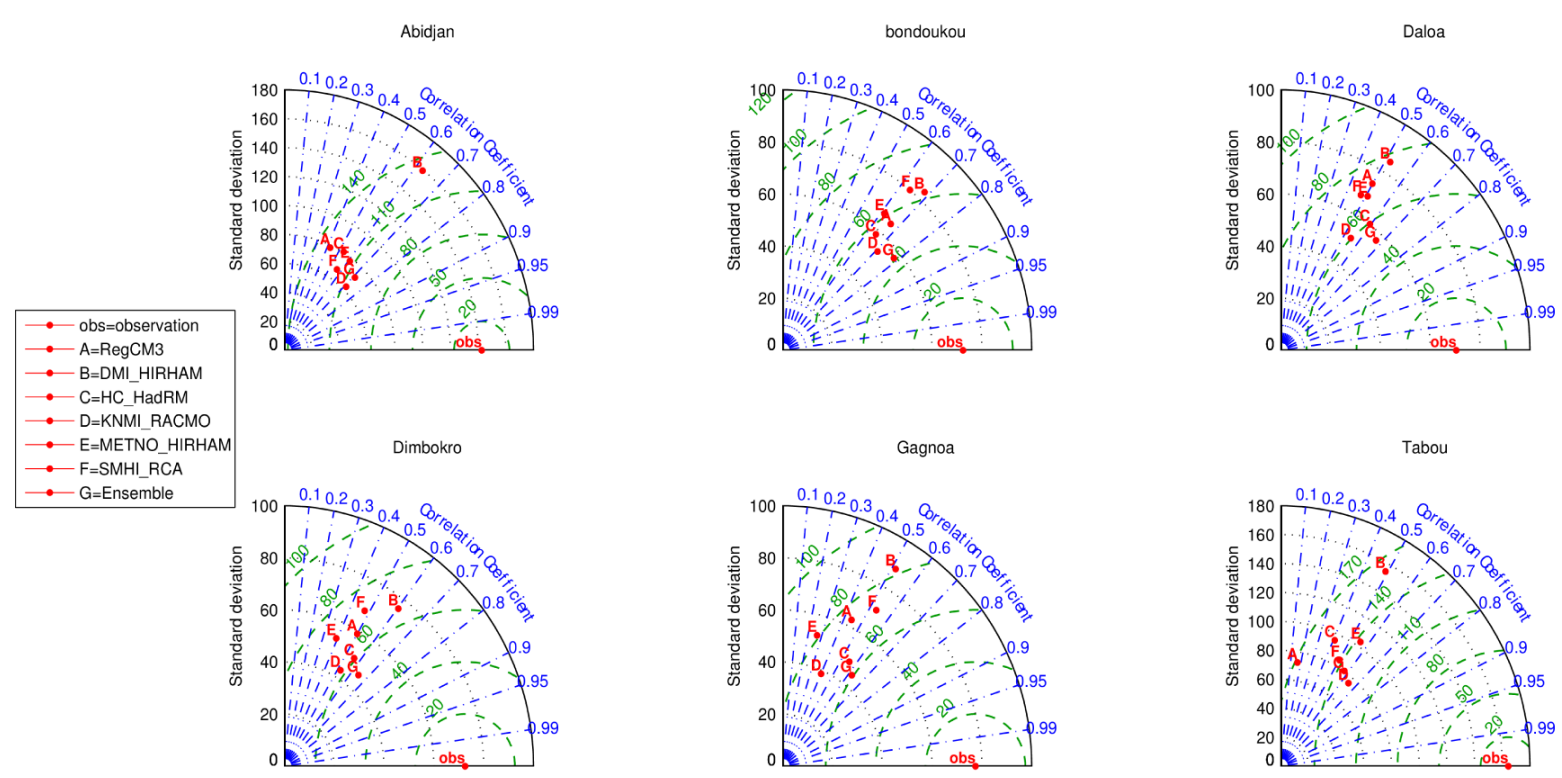

Figure 2. Comparison of monthly precipitation statistics (standard deviation, correlation coefficient, and root mean square) of AMMA-ENSEMBLES data each other and with observation over selected stations in Côte d'Ivoire.

a convergence between the statistics of RegCM3, RACMO, HadRM, METNO-HIRHAM, RCA at the stations of Abidjan and Daloa since they are confined in a small area. In all the models, DMI-HIRHAM precipitation result is the closest to the observation except at Bondoukou and Daloa. This suggests that DMI-HIRHAM has the best skill out of all the models in replicating rainfall with the correlation coefficient of about 0.6 even though the centered root mean square error (RMSE) is to some extent high. The plot of the monthly time series (not shown) for the period (1990-2005) shows that DMI-HIRHAM generally underestimates the rainfall amount. The skill of the model is better over the coastal areas of Tabou and Abidjan than in other areas. The difference between the values of the standard deviation displayed by DMI-HIRHAM and the observation is very low $(\leq 5)$ in Tabou and about 20 in Abidjan while the rest of the models are up to about 40. In this littoral area (Abidjan and Tabou), all the models except DMI-HIRHAM have a standard deviation around 80 while the standard deviation of the observation is about 140 . This high difference expresses low amplitude of variation on the simulated rainfall compare to the observed. In addition, the high RMSE suggests over or under estimation of precipitation by models. DMI-HIRHAM shows a variation relatively close to the observed with high correlation coefficient, but it has a high RMSE. Beyond the coastal zone, the models display closer results to the observation. For instance, at Bondoukou while the standard deviation of the observation is 70 , the standard deviation of the simulated is between 50 and 70 with a correlation coefficient above 0.6. In these stations the RMSE has its smallest values (less than 80 ) while along the coast the value is above 100 . The ensemble mean presents the highest correlation coefficients of $>0.7$ except at Daloa. The variation of this ensemble seems not in good agreement with the observation. The difference between the standard deviation of the observation and ensemble is above 70 . At Tabou and Abidjan, at the station of Gagnoa and Dimbokro this difference is $\sim 30$. The most right variation display with ensemble compare to the observation is obtained at the stations of Daloa and Bondoukou.

In order to check the performance of each model over Côte d'Ivoire, the considered six stations were averaged for the observation, the model outputs and the ensemble mean. This may represent a summary of the performance of each model and the ensemble over the entire domain. Figure 3 shows that DMI-HIRHAM model result is quite different to the other models. In fact DMI-HIRHAM standard deviation is closest to the observed while the other models and the ensemble present less standard deviation than the observation. This model DMI-HIRHAM has a high correlation coefficient ( 0.6) however the RMSE is high (110) that means a simulated amount is different from the observation. The models RegCM3, RCA, METNO-HIRHAM, HadRM have RMSE value $\sim 95$, and correlation coefficient between 0.4 and 0.6 and the difference between their standard deviations and the observed is about 30. The model RACMO present the smallest value of RMSE ( 80) and the highest correlation coefficient ( $\sim .63)$ however the difference between its standard deviation and the observation 
one is about 40. On the following sections, the annual cycle of the precipitation and the time series at each selected station (Figure 4) and its associate statistics in Taylor Diagram (Figure 5) are presented and discussed. This is to further analyze the model for their capability in replicating the mean variation of the precipitation over the year and how close the models representation are to the observation.

\subsubsection{Simulation of Annual Cycle of Rainfall}

Figure 4 shows the seasonal variability of precipitation in the six stations considered. The bimodal nature of the rainy season is clearly shown by all the models even though they did not accurately replicate the magnitude.
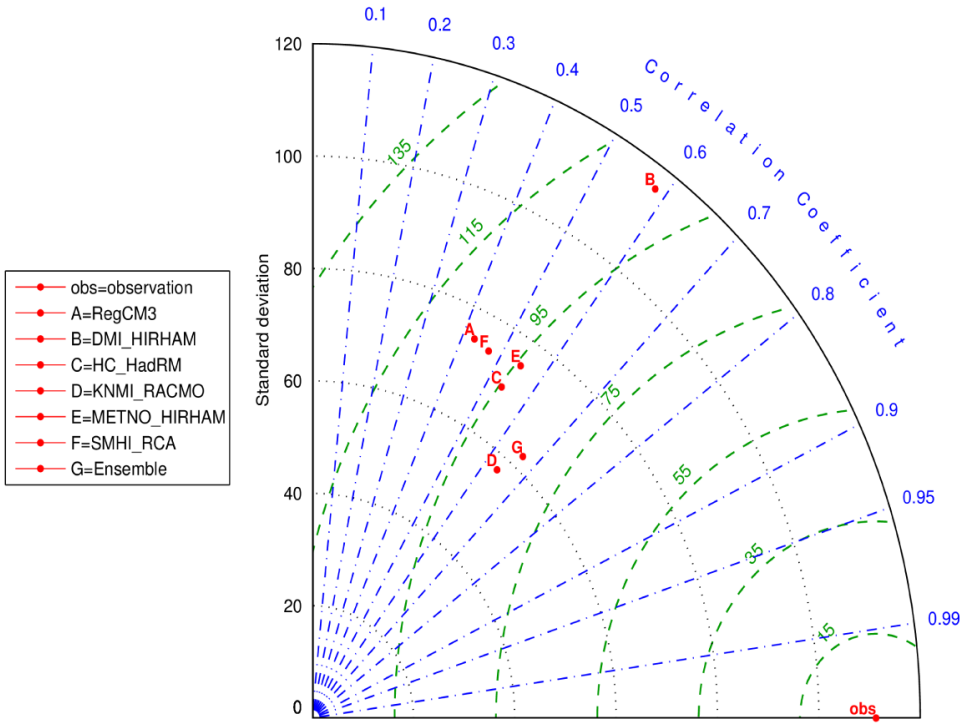

Figure 3. Comparison of monthly precipitation statistics (standard deviation, correlation coefficient, and root mean square) of AMMA-ENSEMBLES data each other and with observation over all the entire stations combined in a single one.
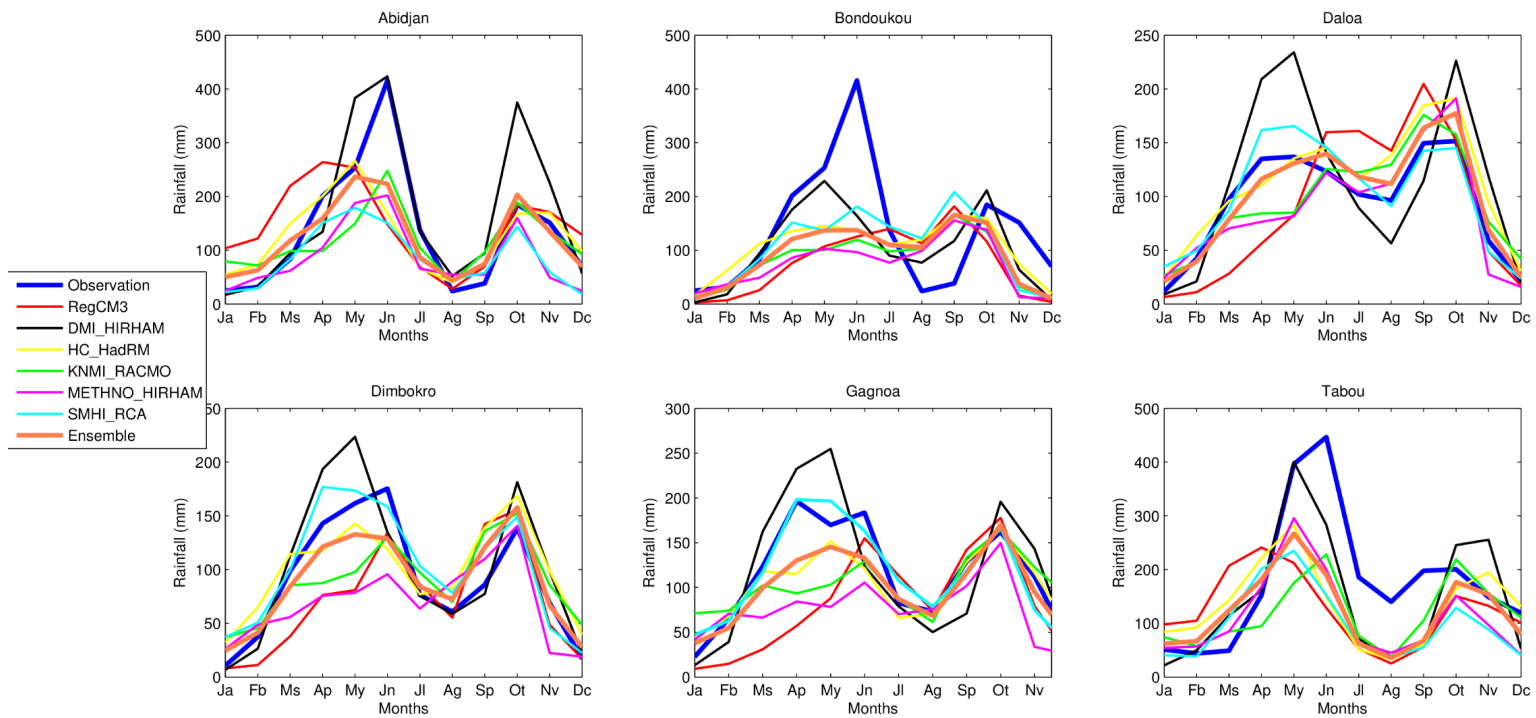

Figure 4. Annual cycle of precipitation computed over the period 1990-2005. 

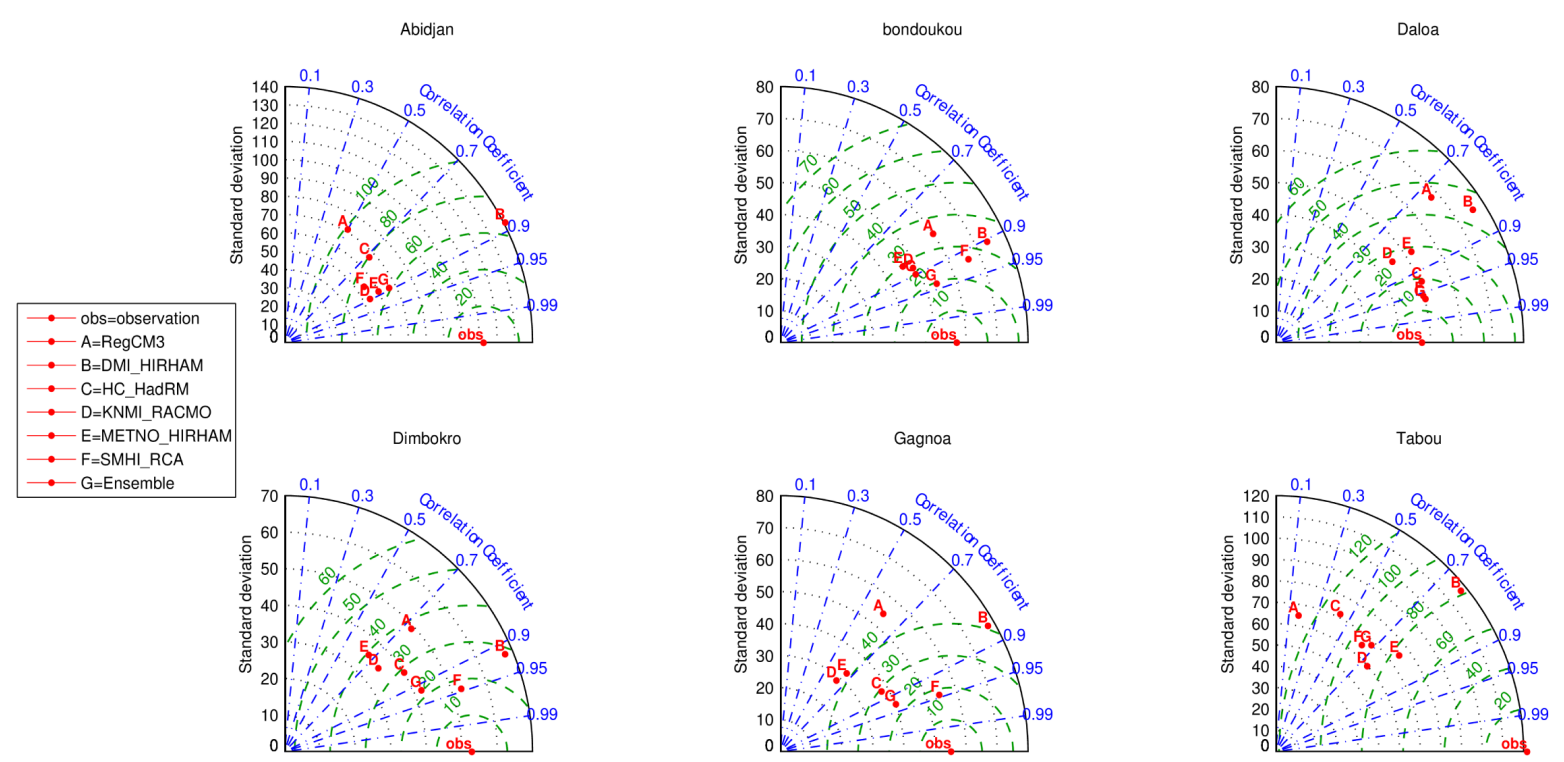

Figure 5. Comparison of precipitation annual cycle statistics (standard deviation, correlation coefficient, and root mean square) of AMMA-ENSEMBLES data each other and with observation over selected stations in Côte d'Ivoire.

DMI-HIRHAM presents the closest variation compared to the observation in Abidjan, Daloa and Gagnoa. In Abidjan, DMI-HIRHAM replicates the variation in the first peak of rainfall season and a wet bias in the second peak; this was corroborated by the Taylor diagram presented (Figure 5). In that station, all other models were at various degrees of dry biases. In Daloa, Dimbokro and Gagnoa, DMI-HIRHAM demonstrates highest wet bias while other models were at varying degree of accuracy as compared to the observation. The result of the seasonal variability corroborates the result of Taylor plot presented in earlier section. The ensemble mean shows a realistic variation of precipitation but pain to replication of the magnitude. In Abidjan, Dimbokro, and Gagnoa, ensemble replicates the variation while it underestimates the first maximum. There is a lag in the indication of the month of maxima rainfall between the ensemble mean and the observation. This is clearly seen at the station of Daloa where this ensemble indicates the first maximum in June while the observation shows the same event in April-June. At the station of Bondoukou, the second maximum of rain is in October in the observation while the ensemble simulates it one month earlier. Overall the second rainy season is relatively well captured in comparison to the first season. In all the stations, the ensemble shows high value of correlation coefficient, low value of the centered root mean square error and has confident standard deviation. For example at Bondoukou and Daloa the correlation coefficients are above 0.95, with a standard deviation similar to the observed. Low RMSE makes ensemble closest to the observation in the simulation of the annual cycle as compared to the result of individual models.

\subsubsection{Seasonal Analysis}

The season May-June corresponds to the intensification of the first and major rainy season in the southern part of the country followed by a shift toward the northern part and beyond [9]. In fact, [9] focusing in the monsoon dynamics found out that July-August is the Little Dry Season (LDS) in the southern part and the period of intensification of the monsoon rain in the northern part. September-October correspond to the retreat of the rain belt toward the south. It is then the second and short rainy season in southern part of the country [28] [31]. Therefore a good performance of a model at any of these seasons maybe very important in the seasonal forecast of climate in Côte d'Ivoire and generally over West Africa since rainfall is one of the most important indicators of the monsoon variability [32].

Interannual evolution of the seasons; May-June, July-August, and September-October from 1990 to 2005 is analyzed over the selected six stations in Côte d'Ivoire. Time series computed on these seasons show that all the models pain to simulate the interannual evolution of these seasons (figures not shown). The amount of precipitation is somehow not well estimated, the computed correlation coefficients between models and observation are 
very low (generally $<0.4$ ) with a high RMSE and a standard deviation different for the observation one. For this reason, the ensemble which is the average of all the models, presents less satisfactory results. However for the period May-June the Taylor diagram shows that at Bondoukou, there is a good representation of the season by the model METNO-HIRHAM with a high correlation coefficient ( 0.75) and a relative low RMSE. In September-October only the ensemble shows a result sensibly close to the observation especially at Bondoukou while the models HadRM, RCA and METNO-HIRHAM seem outliers. In July-August at the station of Dimbokro, the model RACMO reproduces fairly well the pattern of the rainfall; it has a standard deviation close to the observation with a correlation coefficient of about 0.6 and relatively low RMSE. In spite of these lackluster performances, the simulation of the mean values of these peaks is reasonably better estimated. In Figure 6 and Figure 7 we computed the mean over the years of the amount of precipitation at the different peaks of the rainy seasons and at the different stations.
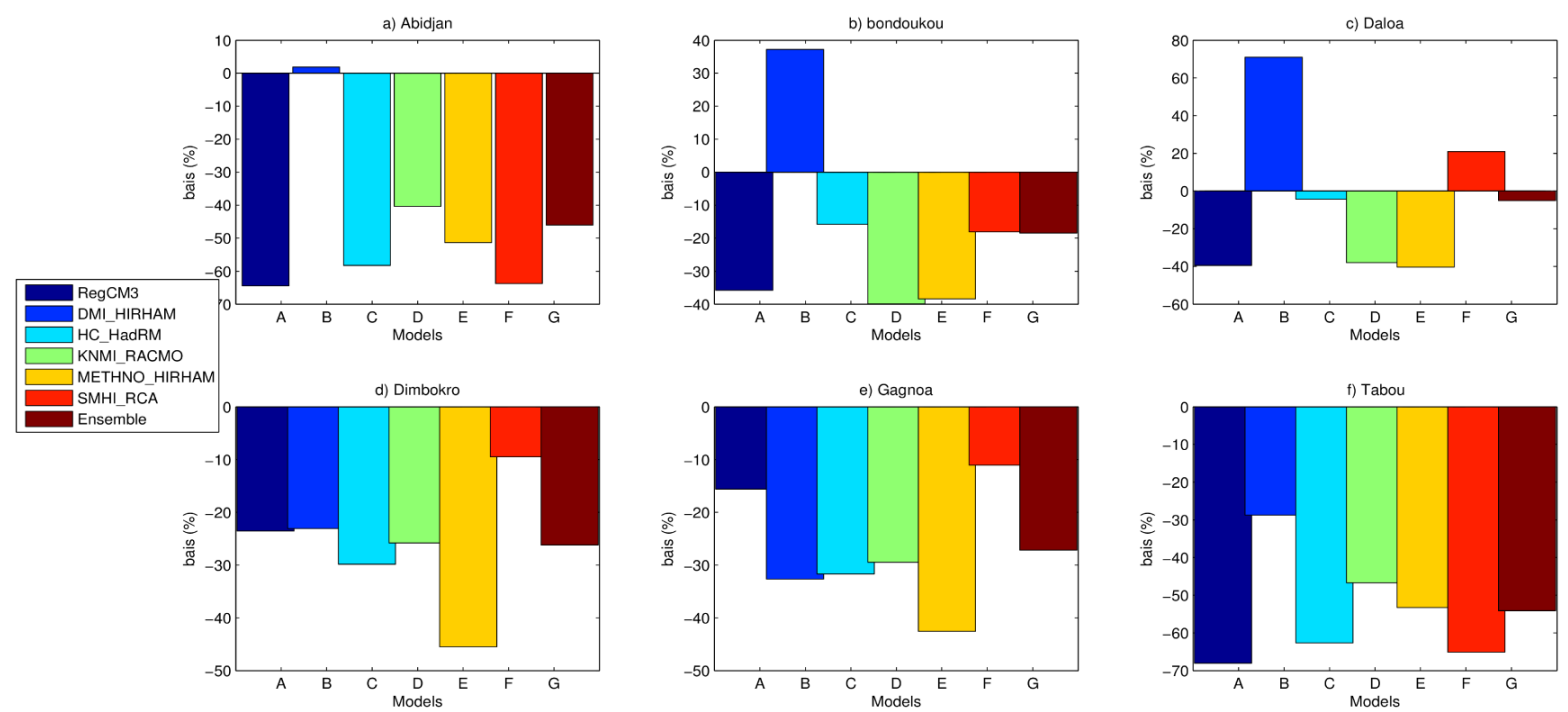

Figure 6. Bias of the mean rainfall amount computed on the month of the first peak of the rainy season over the period 1990 to 2005 .
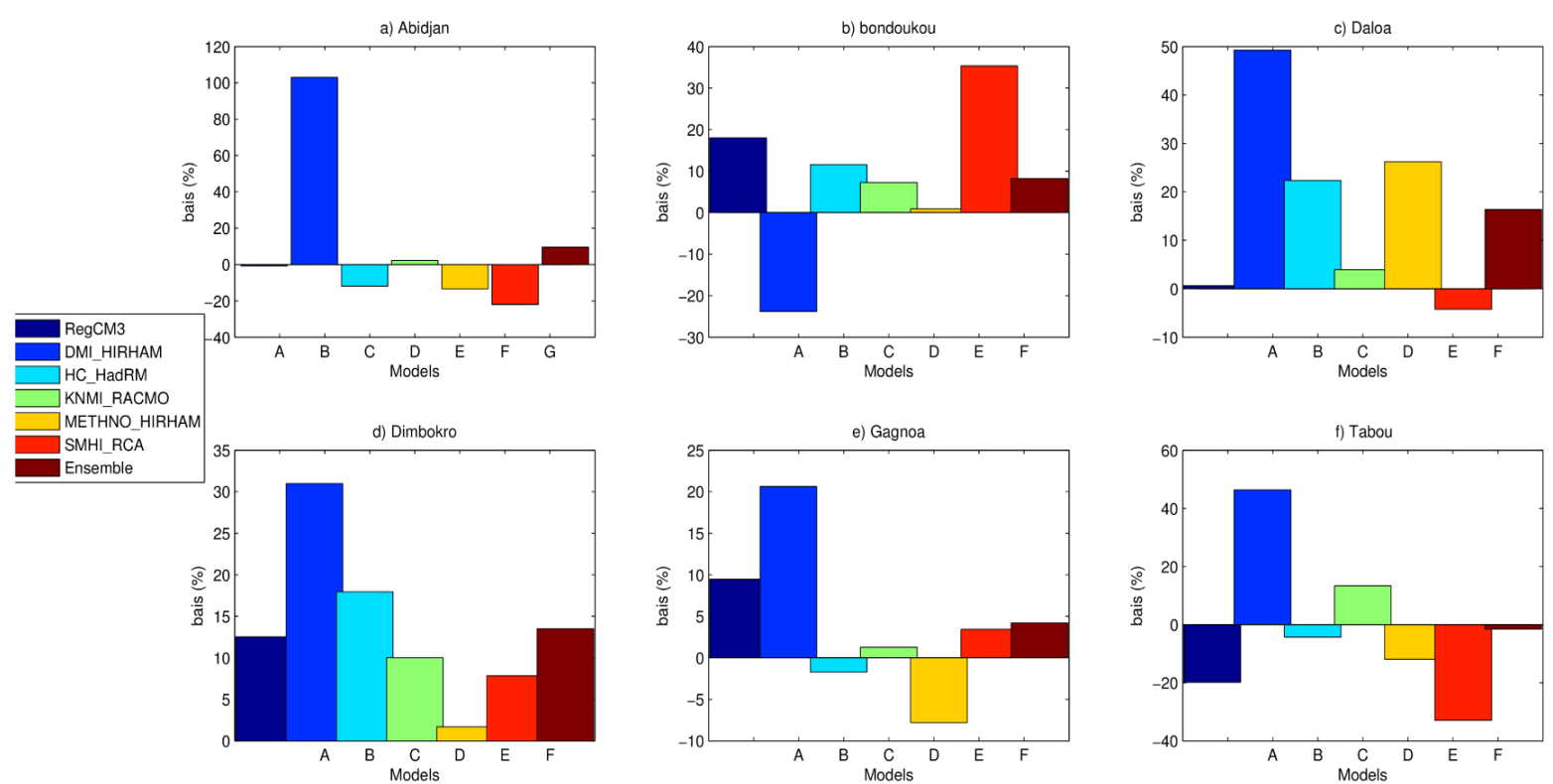

Figure 7. Bias of the mean rainfall amount computed on the month of the second peak of the rainy season over the period 1990 to 2005. 
Figure 6 shows the bias in percentage of each model rain amount simulated compared to the observation for the first peak. The bias is computed in June which, represents the period when this peak occurs at Abidjan, Dimbokro, Gagnoa and Tabou while for Bondoukou and Daloa it occurs in May. Almost all models underestimate the amount of rainfall during the first maximum at all the stations. For example, at Dimbokro, Gagnoa and Tabou all the models show negative bias except DMI-HIRHAM that shows positive bias in Abidjan and Bondoukou. DMI-HIRHAM shows along the coastal areas, the best estimation of the first maximum even though the bias is $\sim-25 \%$ at the station of Tabou. Indeed it exhibits $1.86 \%$ as bias in Abidjan and the bias of $25 \%$ at Tabou is the best. This underlines that DMI-HIRHAM may perform well in the littoral. For the other stations, the models pain to proper estimate the first peak accordingly the ensemble exhibits bias beyond 26\% except at Bondoukou (18\%) and Daloa (5\%).

Figure 7 shows the bias in percentage of the rain amount simulated compared to observation for the second rainfall peak. The bias is computed in October which is the period of this peak in Abidjan, Dimbokro, Gagnoa and Tabou while it occurs in September for Daloa and Bondoukou.

Contrary to the result of the first maxima, there is a good estimation of the second peak. For example, at Abidjan, RegCM3 and RACMO are in good agreement with the observation with respective biases of $-0.66 \%$ and $2.28 \%$. DMI-HIRHAM overestimates the rainfall at that peak, the rests perform well. DMI-HIRHAM shows a bias of $\sim 100 \%$ at Abidjan and overestimates in other stations except in Bondoukou, where it underestimates the amount of rainfall (-23.81\%). At Bondoukou, METNO-HIRHAM performed best with a bias of $0.92 \%$. For this station, three other models are under 20\% of bias (RegCM3, HadRM and RACMO). In summary, there is a good estimation by the models except DMI-HIRHAM of the mean rainfall amount during the second peak of the rainy season at the different stations.

\subsection{Projection Assessment (2010-2013)}

In this section, the accuracy of the scenario used to run the projection of the near future is assessed. Since the different simulations have been run before 2010, this period 2010-2013 is somewhat a great occasion to ascertain the accuracy of the projection over those years before using it for prediction.

\subsubsection{Inter-Seasonal Variability}

Figure 8 shows the time series of the annual cycle of rainfall over the period 2010-2013. The models did not replicate well the inter-seasonal pattern of rainfall. Contrary to bimodal structure of rainfall especially along the coast and the center regions [28], all the models in the present simulation show a unimodal structure. This result may be due to an unsuitable climate change scenario. Indeed this lower performance may be related to error in the input GCMs (ECHAM5-r3, HadCM3Q0) as the models replicated correctly the bimodal structure when driven by ERA-Interim presented in earlier section. Observations show bimodal structure of rainfall in five of the six stations, in Abidjan, Only RegCM replicated this nature of the seasonal cycle while other models show unimodal rainfall in this station contrary to Observation. The models also show dry bias in the first peak of rainfall season and wet bias in October. In all other stations, there was a dry bias in Tabou and in Bondoukou while wet bias in Daloa and Gagnoa. To some reasonable extent however, RegCM and METNO-HIRHAM replicated rainfall structure in Abidjan and Daloa and not well in other areas. The ensemble only performed fairly well at the station Daloa.

\subsubsection{Rainfall Monthly Analysis}

Monthly evolution of the rain at each station is presented in Figure 9. In the coastal stations (Abidjan and Tabou), the ensemble mean of all the models did not accurately pick the daily cycle of the rainfall. In June 2010, the ensemble shows an amount of about $190 \mathrm{~mm}$ while it is observed to above $400 \mathrm{~mm}$ in observations. The ensemble, did not only underestimated the amount of rain but also shift the position of the rainfall maxima, there was lag or lead of one to two months. The more realistic estimation of rain in general is achieved at the station of Bondoukou, Dimbokro and Gagnoa in term of amount and variability even it still have a one-month shift which corroborated by Taylor diagram (figure not shown). At Bondoukou, ensemble did not show the LDS centered in August in the years 2010, 2012 and 2013. For the station of Dimbokro, the ensemble showed unimodal structure of the seasonal cycle over the entire period. Individually, along the littoral, the best estimation is given by METNO-HIRHAM (Figure 9). This result is also supported by the associated Taylor diagram (figure not 

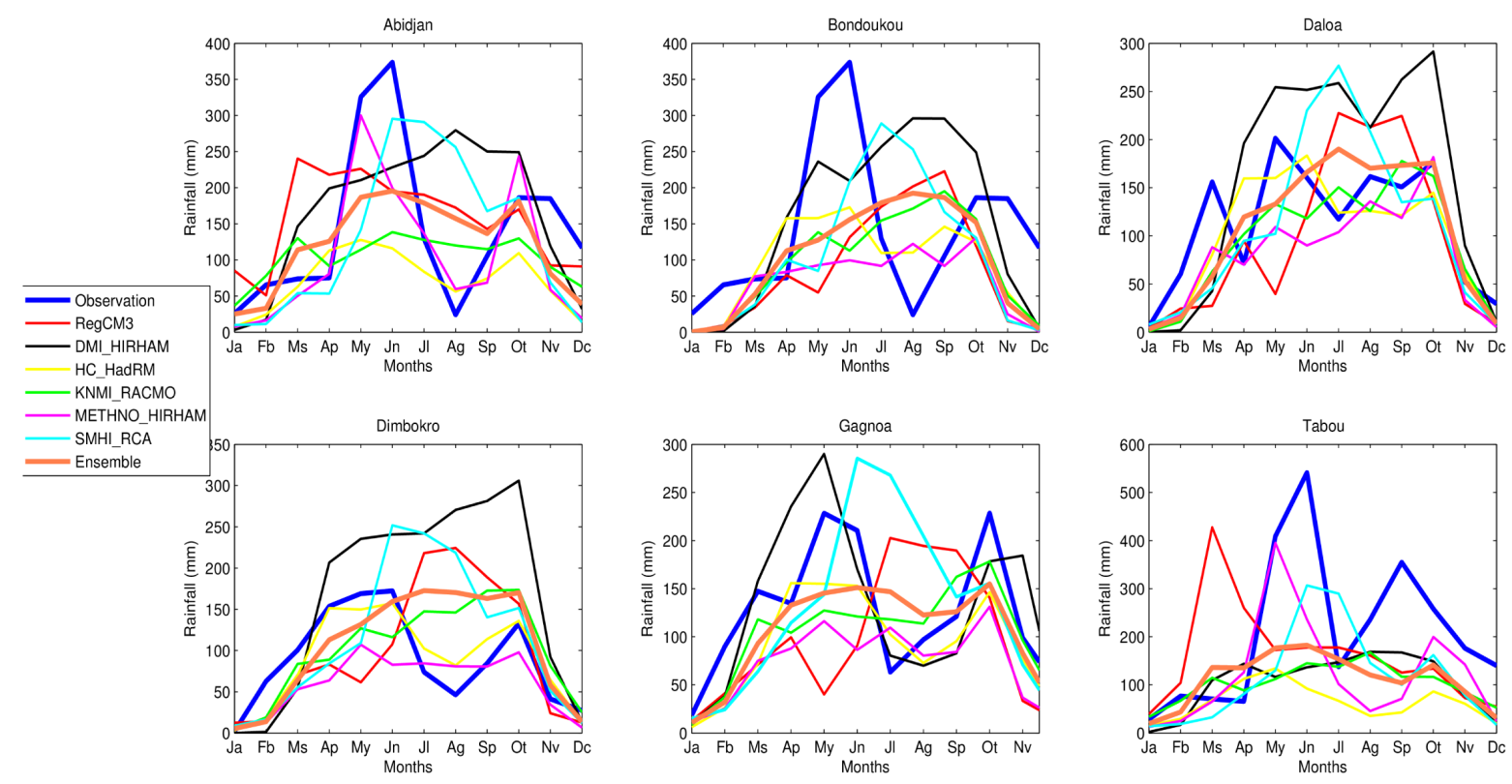

Figure 8. Monthly annual cycle of rainfall computed over the period 2010-2013. The observation data (blue) and the ensemble (orange) have been displayed in bold line. The models output as for them are displayed in fine line.
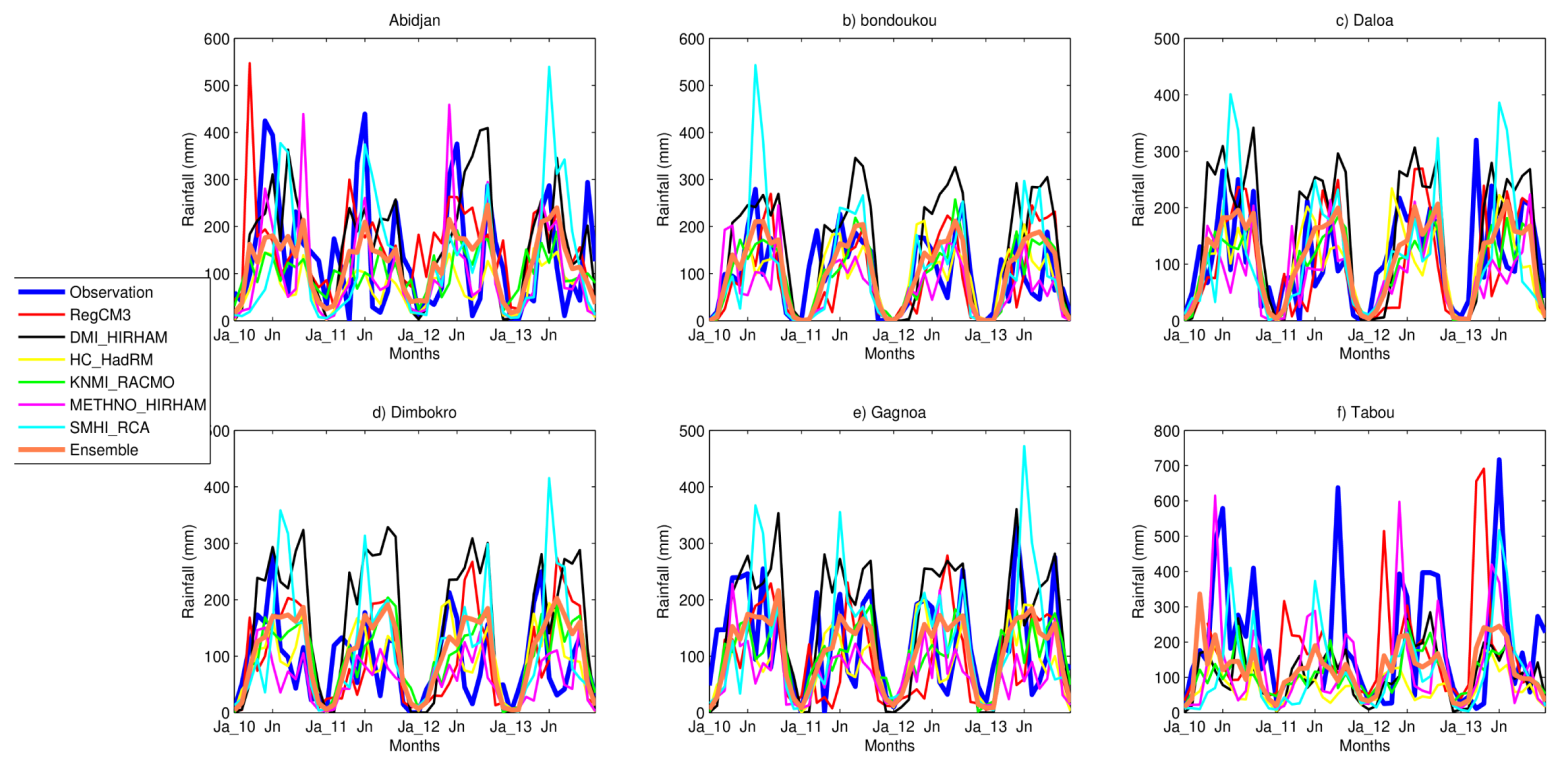

Figure 9. Monthly evolution of rainfall over the period 2010-2013. The observation data (blue) and the ensemble (orange) have been displayed in bold line. The models output as for them are displayed in fine line.

shown), While RACMO and HadRM are in good agreement with the observation in Bondoukou. At Daloa, METNO-HIRHAM, DMI-HIRHAM and HadRM exhibitthe best simulations while only HadRM presents realistic estimation for Gagnoa and Dimbokro.

In order to have a clear idea of the ability of each model in the representation of the seasonal peaks we extracted and plotted these different peaks. The selection of the month is based on the correspondent seasonal cycle. Thus the month of June is selected for first peak for Abidjan, Bondoukou, Dimbokro and Tabou while May for Daloa and Gagnoa. In the second peak, the month of September is only selected for Tabou and while October for the rest (Abidjan, Bondoukou, Daloa, Dimbokro, Gagnoa and Tabou).

Figure 10 shows the bias of the simulated rain amount in first maxima for the period 2010-2013. It is ob- 
served that the models underestimated the rain amount by about $20 \%$ to $80 \%$. In the coastal area, all the models underestimated the amount of rain and only RCA presented a bias under $30 \%$ in Abidjan. Because of the wide gap between the models estimations and the observations, the computed ensemble in the first peak shows a bias above 30\% excepting at Bondoukou (the most northern of the stations used) and Dimbokro (in the center of the country). In this center region, (Dimbokro) HadRM underestimated rainfall by about $8.63 \%$ which is the best estimation, while for the same location it was RCA that performed best for 1990-2005 simulations. At Daloa, DMI-HIRHAM showed a bias under 20\% while in Abidjan and Tabou none of the models showed a bias less than $20 \%$; the lowest is provided by RCA with $-20.98 \%$ of bias. The best estimations by ensemble are observed at Bondoukou and Dimbokro with a bias of $-6.25 \%$ and $-7.46 \%$ respectively. Thus ensemble may be used to have realistic and good projection of the first maximum in the coastal region of the country.

The bias of the simulated rain amount for the second maximum is shown in Figure $\mathbf{1 1}$ for the period 2010-
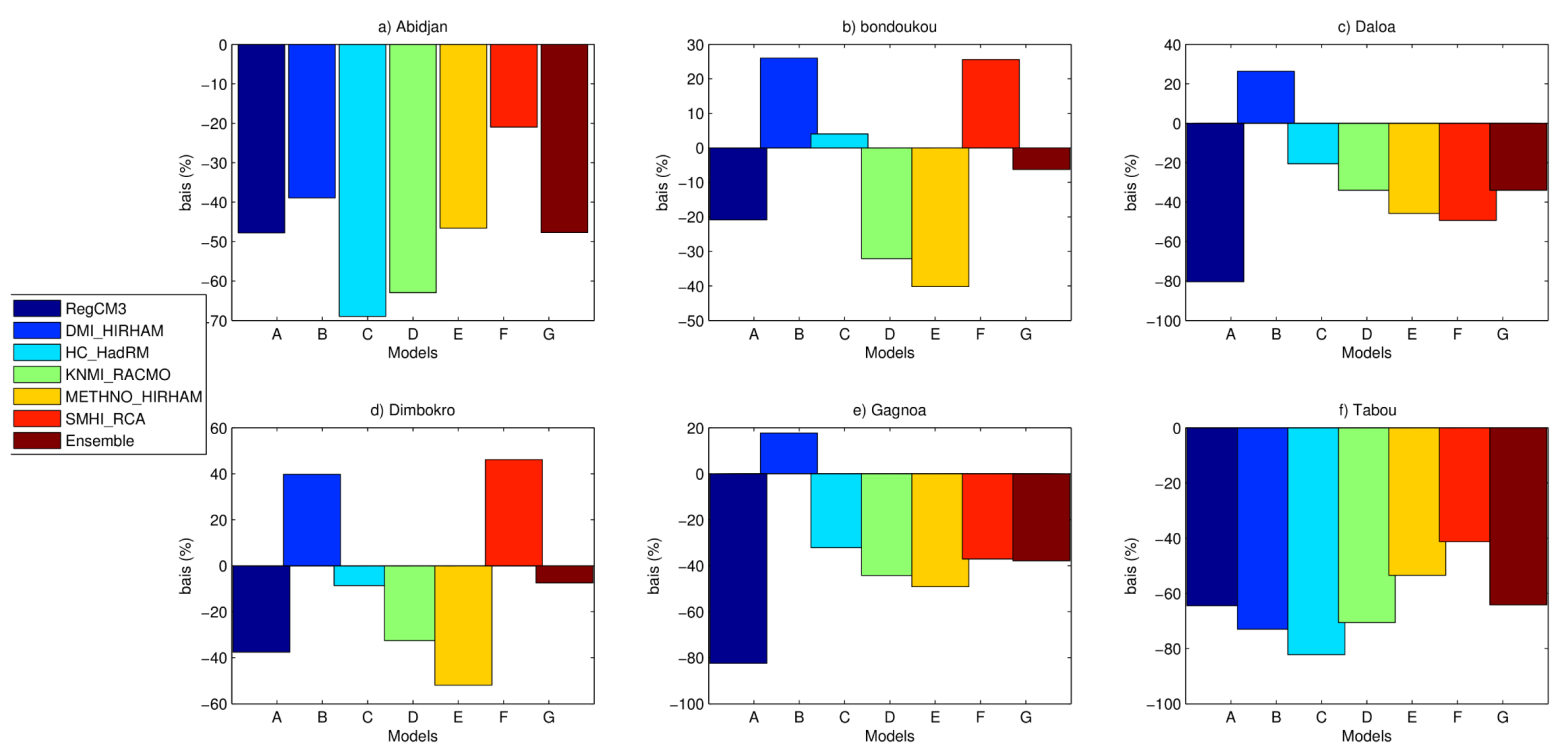

Figure 10. Bias of the mean rainfall amount computed on the month of the first peak of the rainy season over the period 2010-2013.
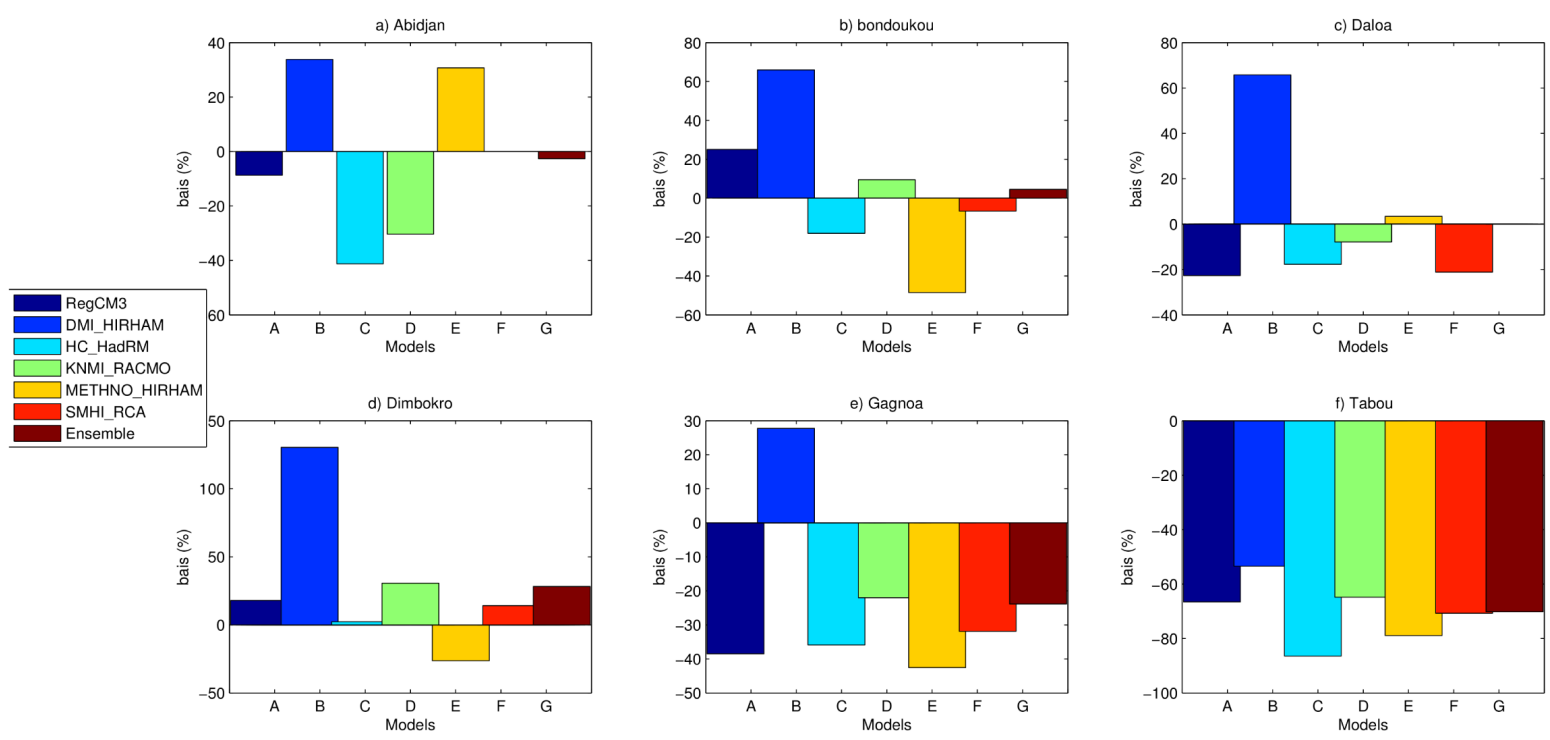

Figure 11. Bias of the mean rainfall amount computed on the month of the second peak of the rainy season over the period 2010-2013. 
2013. At Tabou, all the models underestimated the maxima of precipitation like for the first peak with a bias of above 50\%. Unlike the simulation of the period 1990-2005 presented in the earlier section, none of the models performed well in the estimation of this event. However for Abidjan, there is no clear tendency for all; some models underestimated while others overestimate. The best estimation is given by RCA $(-0.02 \%$ of bias $)$ followed by RegCM3 (9\% of bias). The computed ensemble displayed a good estimation of this event with 3\% of bias unlike in the first maximum. At Bondoukou the best estimation is given by the ensemble, when among the models, HadRM (7\%) presented the best estimation of the second peak followed by RACMO (9.5\%). METNO-HIRHAM (3\% of bias) gave the closest estimation of the second peak preceded by the computed ensemble ( $0.04 \%$ of bias) and followed by the RACMO (8\%). At Daloa in the center of the country, HadRM performed best with $2 \%$ of bias. In this part ensemble is able to represent the second peak but the bias is little bit high (28\%). In first peak of rainfall season, all the models failed in the estimation of the rainfall amount, while RegCM (-8.70), and RCA (-0.02\%) performed well in the second peak. Ensemble showed satisfactory result except at Tabou which high bias of about $-70.15 \%$. This may indicate that in Tabou, there are some local physical processes that models failed to take into account. In summary, the ensemble mean of all the models outperformed the skill of individual models and gives better estimation of the precipitation amount. It is then considered more suitable for the projection study.

\section{Projection of the West African Climate}

\subsection{Analysis of Rainy Seasons over West Africa for the Period 1990-2005 and 2020-2040}

This part of the work is the projection of the West African climate over 2020-2040. Because of the result in the previous sections, we used the ensemble mean of the models. In fact the previous sessions of this work emphasized the improvement of representation of rainfall pattern when using ensemble. In addition, [19] [20] [22] [23] independently showed that ensemble mean outperformed the skill of almost all the individual models. Attention is given to the seasons June-September (JJAS) which is the rainy season in the Sahel, May-July (MJJ) and September-November (SON). MJJ and SON is the first and second rainy season respectively in the Guinean coast area. Figure 12 shows the difference between mean rainfall of 1990-2005 and 2020-2040 for the seasons JJAS, MJJ and SON. There is for all the considered seasons, a decrease in the amount of rainfall over the north and an increase in the south in 2020-2040 compare to the reference period (1990-2005). During the season JJAS, the neutral (stationary) area (limit between area of decrease and increase) is located around $10^{\circ} \mathrm{N}$. The stationary zone is located around $5^{\circ} \mathrm{N}$ during MJJ and SON. It's seemed that this neutral area follows the mean position of the ITD. [9] [34] showed that the mean positions of the ITD are located around these latitudes respectively during these periods. The maximum of precipitation between May and beginning of June is over the Gulf of Guinea $\left(0^{\circ} \mathrm{N}-6^{\circ} \mathrm{N}\right)$. This rain belt shifts around $10^{\circ} \mathrm{N}$ between mid-June and early July then move back to Gulf of Guinea in September. Furthermore the northern part (Sahelian zone) is well known to have less precipitation than the southern part. Thus this led to conclude that the area which has less precipitation will be drier and the zone which has more precipitation will be wetter. This suggests an increase climatic stresses for the local population who depend exclusively on monsoon rainfall for livelihood. There may also be an increase in the probability of drought and flood events in the north and the south respectively. This is in agreement with the work done of [33] that supposed a prevailing drying tendency in sub-Saharan Africa. However there are divergent results over the coastal region. Indeed this southern zone may have more precipitation contrary to [33] who report likely deficit of precipitation over this zone.

\subsection{Changes in Precipitation Interannual Variability in Regard to 1990-2005 of Three Different Basins over West Africa}

The effect of changing climate on three basins over the region is presented in this section. These basins are Volta basin (south and north), Senegal basin and the Bandama basin. The first two basins were selected because of their impact on socio-economic activities of the surrounding countries. The third one gives idea of evolution of rivers over Côte d'Ivoire and their associated impacts. This section focuses on the yearly evolution of precipitation over the season May-October (MJJASO) which is rainfall season in these areas. Figure 13 shows an expected that the basins located in the south received more precipitation than those in the north. For instance, the Bandama and the Volta south basins have their mean value around $900 \mathrm{~mm}$ for the period 1990-2005 and 1100 mm over the period 2020-2040 while the northern basins obtained less than $900 \mathrm{~mm}$ of rain. In fact, the northern 

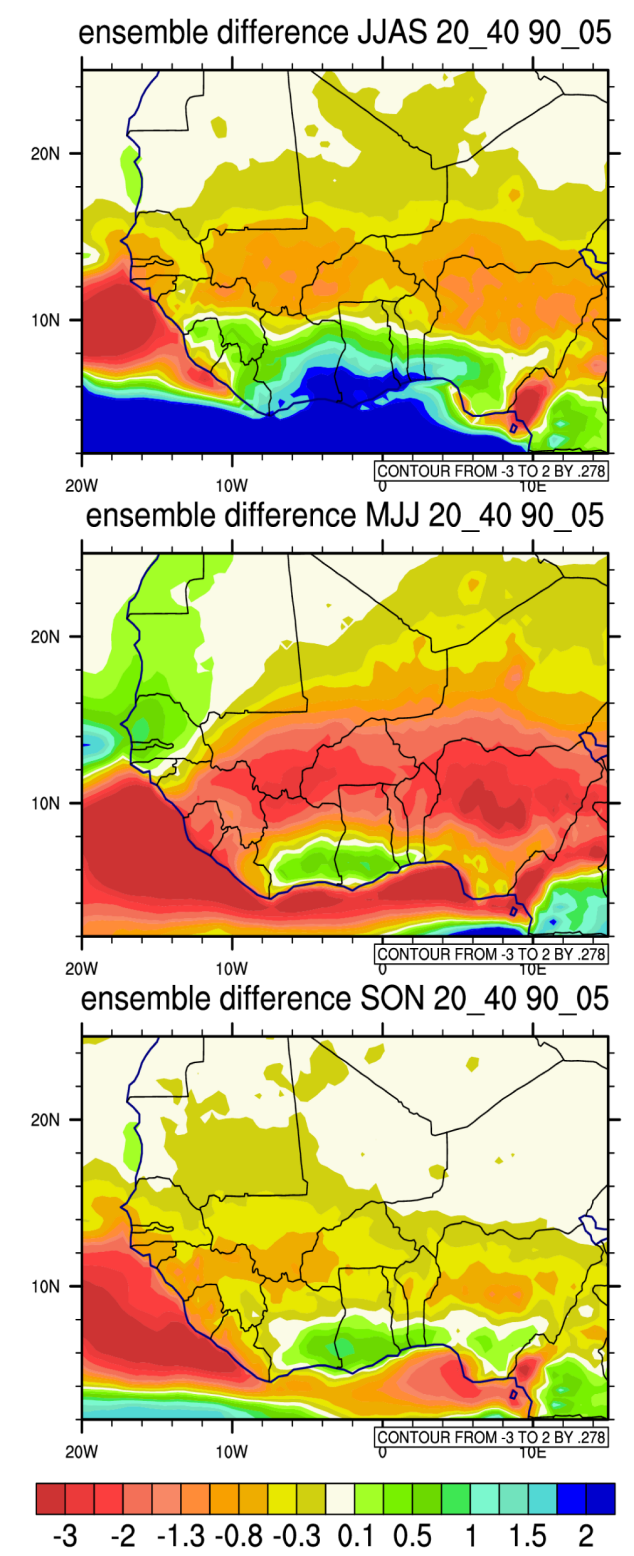

Precipitation Ensemble mean 2020-2040

Figure 12. Ensemble mean difference of the periods 1990-2005 and 20202040 computed over the seasons JJAS, MJJ and SON.

part of Volta basin has a mean value around $800 \mathrm{~mm}$ for both 1990-2005 and 2020-2040 periods. Over the Senegal basin, the mean value fluctuated around $650 \mathrm{~mm}$ for the period 1990-2005 and $600 \mathrm{~mm}$ for the period 2020-2040. This result is in agreement with the result obtained in Section 4.1 which suggested an increase in the south (coastal area) and a decrease in the north in the amount of rain even the northern part of the Volta basin showed a steady evolution.

\subsection{Changes in Precipitation Annual Cycle over Volta, Senegal and Bandama Basins}

The annual cycle of the period 2020-2040 has been compared to 1990-2005 in order to have an insight into the inter-seasonal variability in the near future (Figure 14). It was observed that for the basins located in the Sahel, the projection present the same structure while over the Guinean coast this projection shows a modified clima- 

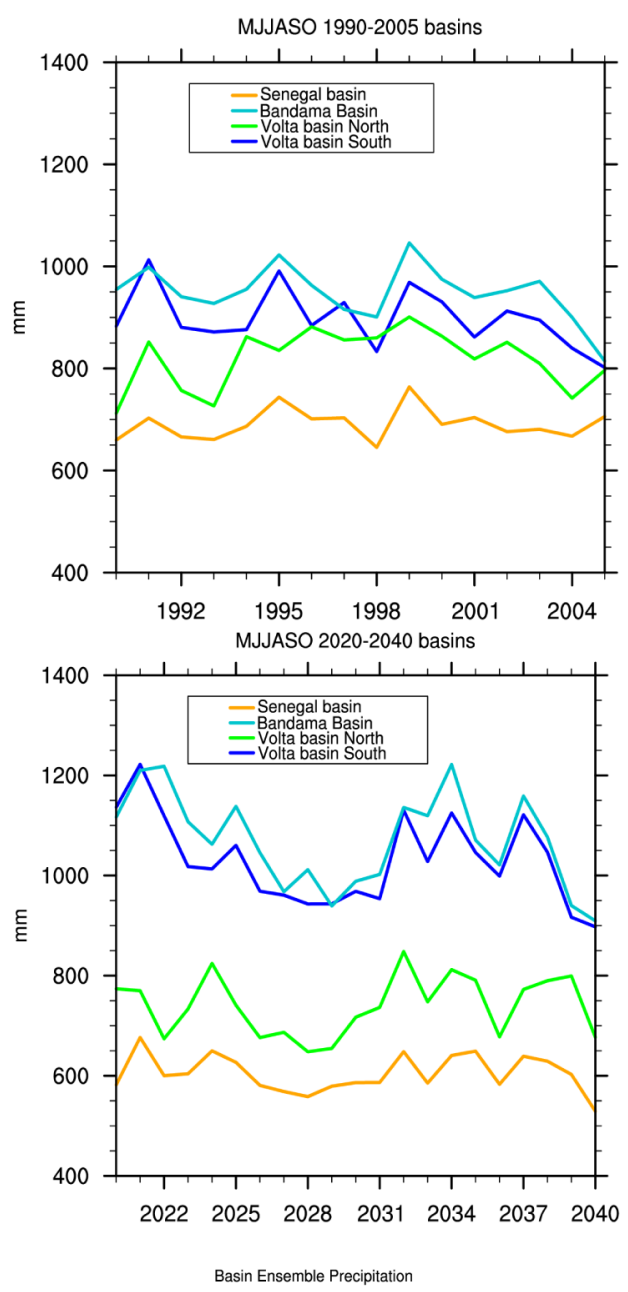

Figure 13. Yearly precipitation ensemble mean computed over Volta, Senegal and Bandama basins for the periods 1990-2005 and 2020-2040.

tology. The simulation shows that in the period 2020-2040, there will be one rainy season for both Sahelian and coastal area regions, which implies the disappearance of LDS and bimodal rainfall regime in the Guinea coast as observed in 1990-2005 (Figure 14(a)). Two possibilities can be deduced from this result. The first one suggests that there may be modification of the climate over the Guinean coast which is less plausible and it may be probably inaccuracy of the projection of the models used in this study. The period 2010-2013 has been considered to check the first surmise which is related to the modification of variability of the annual cycle over theses basins. Thus the annual cycle of the rainfall from the ensemble mean is compared to the TRMM data (figure not shown). As we expected, this ensemble mean showed once again a unimodal rainfall pattern while TRMM exhibited a bimodal rainy season over the coastal area. Therefore it seems that the scenario consider to run the simulations was not too realistic to be able to capture the climatic features of the Guinean coast region. In agreement of this, many studies [33] [35] pointed out the inherent problems of Regional Climate Models (RCMs) on future precipitation change in West Africa.

\section{Conclusions}

The study consisted of the assessment of the ability of RCMs from AMMA-ENSEMBLES in their basic representation of the rain pattern. So the most suitable RCMs would be identified for climate study and policy maker in Côte d'Ivoire in particularly and generally over West Africa. The evaluation, first time period (1990-2005), consisted of time series and statistical (Taylor diagram) analyses over six stations while the second set (2010- 

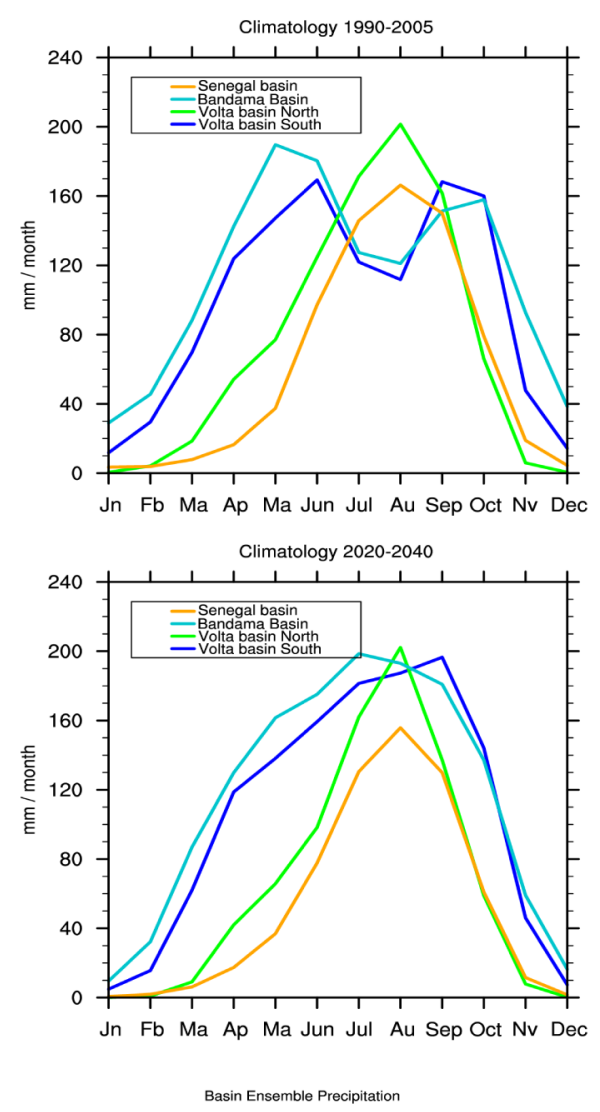

Figure 14. Annual cycle average rainfall computed for the periods 1990-2005 and 2040-2040 over the Volta, Senegal and Bandama basins.

2013), was used to evaluate either the ability of these AMMA-ENSEMBLES data to predict the near future or to check the accuracy of the scenario used for this projection. The last part consisted of the analysis of the coming changes (2020-2040) according the reference period (1990-2005).

The analysis of the validation experiment indicates a performance of RCMs varying with the focus of interest. Some models are relatively good in retrieving the first rainfall peak, case of DMI-HIRHAM in the coastal area, while RegCM3, HadRNM3, RACMO, METNO-HIRHAM and KNMI_RACMO show good performance in reproducing the second peak. However, the computed ensemble mean presents a representation close to the observation. This emphasizes that the use of ensemble mean outperforms the skills of almost all the single RCM either in magnitude or spatial distribution. Thus, it illustrates the advantage of multi-models assessment of the WAM rainfall as presented in previous studies [20] [22] [33] [36].

The projection for period 2020-2040 over West Africa reveals decreasing amount of rainfall at the north of $10^{\circ} \mathrm{N}$ and an increase at the south of $10^{\circ} \mathrm{N}$. This result suggests a rise of climatic stresses on local population, namely, an augmentation of probability of drought in the northern part and flood in the southern part. There is however limitation in the accuracy of this projection especially over the Guinea coast in the replication of the annual cycle. It seems that the scenario used in the simulations is not able to capture all the features of the variability of the rainfall in the West African coastal area. The elaboration of future scenarios that take into account the specificity of the southern part of West African climate might be necessary to make better and realistic projections. Furthermore, simulation of the climate at finer resolution may contribute to a better representation of physical processes of this region.

\section{Acknowledgements}

We gratefully acknowledge the West African Science Service Center on Climate Change and Adapted Land Use (WASCAL) which provides a fully support to Kouakou KOUADIO. 
The ENSEMBLES data used in this work was funded by the EU FP6 Integrated Project ENSEMBLES (Contract number 505539) whose support is gratefully acknowledged.

We also thank Risquehydrométéorologiquedans les villes Africaines (RHYV A) for its contribution.

\section{References}

[1] Rodríguez-Fonseca, B., Janicot, S., Mohino, E., Losada, T., Bader, J., Caminade, C., et al. (2011) Interannual and Decadal SST-Forced Responses of the West African Monsoon. Atmospheric Science Letters, 12, 67-74. http://dx.doi.org/10.1002/asl.308

[2] Fontaine, B., Garcia-Serrano, J., Roucou, P., Rodriguez-Fonseca, B., Losada, T., Chauvin, F., et al. (2010) Impacts of Warm and Cold Situations in the Mediterranean Basins on the West African Monsoon: Observed Connection Patterns (1979-2006) and Climate Simulations. Climate Dynamics, 35, 95-114. http://dx.doi.org/10.1007/s00382-009-0599-3

[3] Lamb, P.J. (1978) Case Studies of Tropical Atlantic Surface Circulation Patterns during Recent Sub-Saharan Weather Anomalies: 1967 and 1968. Monthly Weather Review, 106, 482-491. http://dx.doi.org/10.1175/1520-0493(1978)106<0482:CSOTAS>2.0.CO;2

[4] Betts, A.K., Ball, J.H., Beljaars, A.C.M., Miller, M.J. and Viterbo, P.A. (1996) The Land Surface-Atmosphere Interaction: A Review Based on Observational and Global Modeling Perspectives. Journal of Geophysical Research, 101, 7209. http://dx.doi.org/10.1029/95JD02135

[5] Koster, R.D. (2003) Observational Evidence That Soil Moisture Variations Affect Precipitation. Geophysical Research Letters, 30. http://dx.doi.org/10.1029/2002GL016571

[6] Boone, A.A., Poccard-Leclercq, I., Xue, Y., Feng, J. and de Rosnay, P. (2010) Evaluation of the WAMME Model Surface Fluxes Using Results from the AMMA Land-Surface Model Intercomparison Project. Climate Dynamics, 35, 127-142. http://dx.doi.org/10.1007/s00382-009-0653-1

[7] Pal, J.S. and Eltahir, E.A.B. (2003) A Feedback Mechanism between Soil-Moisture Distribution and Storm Tracks. Quarterly Journal of the Royal Meteorological Society, 129, 2279-2297. http://dx.doi.org/10.1256/qj.01.201

[8] Taylor, C.M., Parker, D.J., Lloyd, C.R. and Thorncroft, C.D. (2005) Observations of Synoptic-Scale Land Surface Variability and Its Coupling with the Atmosphere. Quarterly Journal of the Royal Meteorological Society, 131, 913-937. http://dx.doi.org/10.1256/qi.04.119

[9] Sultan, B. and Janicot, S. (2000) Abrupt Shift of the ITCZ over West Africa and Intra-Seasonal Variability. Geophysical Research Letters, 27, 3353-3356. http://dx.doi.org/10.1029/1999GL011285

[10] Sultan, B., Janicot, S. and Diedhiou, A. (2003) The West African Monsoon Dynamics. Part I: Documentation of Intraseasonal Variability. Journal of Climate, 16, 3389-3406.

[11] Gallée, H., Moufouma-Okia, W., Bechtold, P., Brasseur, O., Dupays, I., Marbaix, P., et al. (2004) A High-Resolution Simulation of a West African Rainy Season Using a Regional Climate Model. Journal of Geophysical Research: Atmospheres, 109, 1984-2012. http://onlinelibrary.wiley.com/doi/10.1029/2003JD004020/full

[12] Afiesimama, E.A., Pal, J.S., Abiodun, B.J., Gutowski, W.J. and Adedoyin, A. (2006) Simulation of West African Monsoon Using the RegCM3. Part I: Model Validation and Interannual Variability. Theoretical and Applied Climatology, 86, 23-37. http://dx.doi.org/10.1007/s00704-005-0202-8

[13] Segele, Z.T., Leslie, L.M. and Lamb, P.J. (2009) Evaluation and Adaptation of a Regional Climate Model for the Horn of Africa: Rainfall Climatology and Interannual Variability. International Journal of Climatology, 29, 47-65. http://dx.doi.org/10.1002/joc.1681

[14] Druyan, L.M., Fulakeza, M. and Lonergan, P. (2007) Spatial Variability of Regional Model Simulated June-September Mean Precipitation over West Africa. Geophysical Research Letters, 34, Article ID: L18709.

[15] Druyan, L.M., Fulakeza, M. and Lonergan, P. (2008) The Impact of Vertical Resolution on Regional Model Simulation of the West African Summer Monsoon. International Journal of Climatology, 28, 1293-1314. http://dx.doi.org/10.1002/joc.1636

[16] Druyan, L.M., Feng, J., Cook, K.H., Xue, Y., Fulakeza, M., Hagos, S.M., et al. (2010) The WAMME Regional Model Intercomparison Study. Climate Dynamics, 35, 175-192. http://dx.doi.org/10.1007/s00382-009-0676-7

[17] Sylla, M.B., Coppola, E., Mariotti, L., Giorgi, F., Ruti, P.M., Dell’Aquila, A., et al. (2010) Multiyear Simulation of the African Climate Using a Regional Climate Model (RegCM3) with the High Resolution ERA-Interim Reanalysis. Climate Dynamics, 35, 231-247. http://dx.doi.org/10.1007/s00382-009-0613-9

[18] Konare, A., Zakey, A.S., Solmon, F., Giorgi, F., Rauscher, S., Ibrah, S., et al. (2008) A Regional Climate Modeling Study of the Effect of Desert Dust on the West African Monsoon. Journal of Geophysical Research, 113.

http://dx.doi.org/10.1029/2007JD009322 
[19] Diallo, I., Sylla, M.B., Camara, M. and Gaye, A.T. (2013) Interannual Variability of Rainfall over the Sahel Based on Multiple Regional Climate Models Simulations. Theoretical and Applied Climatology, 113, 351-362. http://dx.doi.org/10.1007/s00704-012-0791-y

[20] Gbobaniyi, E., Sarr, A., Sylla, M.B., Diallo, I., Lennard, C., Dosio, A., et al. (2014) Climatology, Annual Cycle and Interannual Variability of Precipitation and Temperature in CORDEX Simulations over West Africa. International Journal of Climatology, 34, 2241-2257. http://dx.doi.org/10.1002/joc.3834

[21] Klutse, N.A.B., Sylla, M.B., Diallo, I., Sarr, A., Dosio, A., Diedhiou, A., et al. (2015) Daily Characteristics of West African Summer Monsoon Precipitation in CORDEX Simulations. Theoretical and Applied Climatology, in press.

[22] Nikulin, G., Jones, C., Giorgi, F., Asrar, G., Büchner, M., Cerezo-Mota, R., et al. (2012) Precipitation Climatology in an Ensemble of CORDEX-Africa Regional Climate Simulations. Journal of Climate, 25, 6057-6078. http://dx.doi.org/10.1175/JCLI-D-11-00375.1

[23] Moufouma-Okia, W. and Rowell, D.P. (2010) Impact of Soil Moisture Initialisation and Lateral Boundary Conditions on Regional Climate Model Simulations of the West African Monsoon. Climate Dynamics, 35, 213-229. http://dx.doi.org/10.1007/s00382-009-0638-0

[24] van der Linden, P. and Mitchell, J.F.B., Eds. (2009) ENSEMBLES: Climate Change and Its Impacts: Summary of Research and Results from the ENSEMBLES Project. Met Office Hadley Centre, Exeter, 160.

[25] Uppala, S., Dee, D., Kobayashi, S., Berrisford, P. and Simmons, A. (2008) Towards a Climate Data Assimilation System: Status Update of ERA-INTERIM. ECMWF Newsletter, 115, 12-18.

[26] Simmons, A., Uppala, S., Dee, D. and Kobayashi, S. (2007) ERA-Interim: New ECMWF Reanalysis Products from 1989 Onwards. ECMWF Newsletter, 110, 25-35.

[27] Sylla, M.B., Diallo, I. and Pal, J.S. (2013) West African Monsoon in State-of-the-Science Regional Climate Models. http://dx.doi.org/10.5772/55140

[28] Kouadio, K.Y., Aman, A., Ochou, A.D., Ali, K.E. and Assamoi, P.A. (2011) Rainfall Variability Patterns in West Africa: Case of Côte d'Ivoire and Ghana. Journal of Environmental Engineering and Science, 5, 1229-1238.

[29] Kouadio, K.Y., Ali, K.E., Zahiri, E.P. and Assamoi, A.P. (2007) Etude de la prédictibilité de la pluviométrie en Côte d'Ivoire durant la période de Juillet à Septembre. Revue Ivoirienne des Sciences et Technologie, 10, 117-134.

[30] Taylor, K.E. (2001) Summarizing Multiple Aspects of Model Performance in a Single Diagram. Journal of Geophysical Research: Atmospheres, 106, 7183-7192.

[31] Odekunle, T.O. and Eludoyin, A.O. (2008) Sea Surface Temperature Patterns in the Gulf of Guinea: Their Implications for the Spatio-Temporal Variability of Precipitation in West Africa. International Journal of Climatology, 28, 15071517. http://dx.doi.org/10.1002/joc.1656

[32] Adefolalu, D.O. (1983) Monsoon Onset in West Africa Application of Satellite Imagery. Archives for Meteorology, Geophysics, and Bioclimatology, Series B, 32, 219-230. http://dx.doi.org/10.1007/BF02273975

[33] Paeth, H., Hall, N.M.J., Gaertner, M.A., Alonso, M.D., Moumouni, S., Polcher, J., et al. (2011) Progress in Regional Downscaling of West African Precipitation. Atmospheric Science Letters, 12, 75-82. http://dx.doi.org/10.1002/asl.306

[34] Janicot, S. (2009) A Comparison of Indian and African Monsoon Variability at Different Time Scales. Comptes Rendus Geoscience, 341, 575-590. http://dx.doi.org/10.1016/j.crte.2009.02.002

[35] Karambiri, H., García Galiano, S.G., Giraldo, J.D., Yacouba, H., Ibrahim, B., Barbier, B., et al. (2011) Assessing the Impact of Climate Variability and Climate Change on Runoff in West Africa: The Case of Senegal and Nakambe River Basins. Atmospheric Science Letters, 12, 109-115. http://dx.doi.org/10.1002/asl.317

[36] Diallo, I., Sylla, M.B., Camara, M. and Gaye, A.T. (2013) Interannual Variability of Rainfall over the Sahel Based on Multiple Regional Climate Models Simulations. Theoretical and Applied Climatology, 113, 351-362. http://dx.doi.org/10.1007/s00704-012-0791-y

[37] Grell, G.A. (1993) Prognostic Evaluation of Assumptions Used by Cumulus Parameterizations. Monthly Weather Review, 121, 764-787. http://dx.doi.org/10.1175/1520-0493(1993)121<0764:PEOAUB >2.0.CO;2

[38] Fritsch, J.M. and Chappell, C.F. (1980) Numerical Prediction of Convectively Driven Mesoscale Pressure Systems. Part II. Mesoscale Model. Journal of the Atmospheric Sciences, 37, 1734-1762. http://dx.doi.org/10.1175/1520-0469(1980)037<1734:NPOCDM>2.0.CO;2

[39] Nordeng, T.E. (1994) Extended Versions of the Convection Parametrization Scheme at ECMWF and Their Impact upon the Mean Climate and Transient Activity of the Model in the Tropics. ECMWF Research Department, Technical Momorandum No. 206, European Centre for Medium Range Weather Forecasts, Reading, UK.

[40] Tiedtke, M. (1989) A Comprehensive Mass Flux Scheme for Cumulus Parameterization in Large-Scale Models. Monthly Weather Review, 117, 1779-1800. http://dx.doi.org/10.1175/1520-0493(1989)117<1779:ACMFSF>2.0.CO;2 
[41] Kain, J.S. and Fritsch, J.M. (1990) A One-Dimensional Entraining/Detraining Plume Model and Its Application in Convective Parameterization. Journal of the Atmospheric Sciences, 47, 2784-2802. http://dx.doi.org/10.1175/1520-0469(1990)047<2784:AODEPM>2.0.CO;2

[42] Gregory, D. and Rowntree, P.R. (1990) A Mass Flux Convection Scheme with Representation of Cloud Ensemble Characteristics and Stability-Dependent Closure. Monthly Weather Review, 118, 1483-1506. http://dx.doi.org/10.1175/1520-0493(1990)118<1483:AMFCSW>2.0.CO;2

[43] Gregory, D. and Allen, S. (1991) The Effect of Convective Scale Downdrafts upon NWP and Climate Simulations. Proceedings of the Ninth Conference on Numerical Weather Prediction, Denver, 14-18 October 1991, 122-123.

[44] Kiehl, J.T., Hack, J.J., Bonan, G.B., Boville, B.A. and Briegleb, B.P. (1996) Description of the NCAR Community Climate Model (CCM3). Technical Note, National Center for Atmospheric Research, Boulder, CO (United States). Climate and Global Dynamics Div. http://www.osti.gov/scitech/biblio/442361

[45] Giorgetta, M.A. and Wild, M. (1995) The Water Vapour Continuum and Its Representation in ECHAM4. http://pubman.mpdl.mpg.de.sci-hub.org/pubman/faces/viewItemOverviewPage.jsp?itemId=escidoc:2032326

[46] Morcrette, J.-J. (1991) Radiation and Cloud Radiative Properties in the European Centre for Medium Range Weather Forecasts Forecasting System. Journal of Geophysical Research: Atmospheres, 96, 9121-9132.

[47] Fouquart, Y. and Bonnel, B. (1980) Computations of Solar Heating of the Earth's Atmosphere—A New Parameterization. Beiträge zur Physik der Atmosphäre, 53, 35-62.

[48] Savijärvi, H. (1990) Fast Radiation Parameterization Schemes for Mesoscale and Short-Range Forecast Models. Journal of Applied Meteorology, 29, 437-447. http://dx.doi.org/10.1175/1520-0450(1990)029<0437:FRPSFM>2.0.CO;2

[49] Sass, B.H., Rontu, L. and Räisänen, P. (1994) HIRLAM-2 Radiation Scheme: Documentation and Tests. HIRLAM.

[50] Edwards, J.M. and Slingo, A. (1996) Studies with a Flexible New Radiation Code. I: Choosing a Configuration for a Large-Scale Model. Quarterly Journal of the Royal Meteorological Society, 122, 689-719. http://dx.doi.org/10.1002/qj.49712253107

[51] Holtslag, A.A.M., De Bruijn, E.I.F. and Pan, H.L. (1990) A High Resolution Air Mass Transformation Model for Short-Range Weather Forecasting. Monthly Weather Review, 118, 1561-1575. http://dx.doi.org/10.1175/1520-0493(1990)118<1561:AHRAMT>2.0.CO;2

[52] Louis, J.-F. (1979) A Parametric Model of Vertical Eddy Fluxes in the Atmosphere. Boundary-Layer Meteorology, 17, 187-202. http://dx.doi.org/10.1007/BF00117978

[53] Cuxart, J., Bougeault, P. and Redelsperger, J.-L. (2000) A Turbulence Scheme Allowing for Mesoscale and LargeEddy Simulations. Quarterly Journal of the Royal Meteorological Society, 126, 1-30. http://dx.doi.org/10.1002/qj.49712656202

[54] Wilson, C.A. (1992) Vertical Diffusion. Unified Model Documentation Paper, 4.

[55] Brinkop, S. and Roeckner, E. (1995) Sensitivity of a General Circulation Model to Parameterizations of Cloud-Turbulence Interactions in the Atmospheric Boundary Layer. Tellus A, 47, 197-220. http://dx.doi.org/10.1034/j.1600-0870.1995.t01-1-00004.x

[56] Pal, J.S., Small, E.E. and Eltahir, E.A. (2000) Simulation of Regional-Scale Water and Energy Budgets: Representation of Subgrid Cloud and Precipitation Processes within RegCM. Journal of Geophysical Research: Atmospheres, 105, 29579-29594.

[57] Sundqvist, H. (1978) A Parameterization Scheme for Non-Convective Condensation including Prediction of Cloud Water Content. Quarterly Journal of the Royal Meteorological Society, 104, 677-690. http://dx.doi.org/10.1002/qj.49710444110

[58] Rasch, P.J. and Kristjánsson, J.E. (1998) A Comparison of the CCM3 Model Climate Using Diagnosed and Predicted Condensate Parameterizations. Journal of Climate, 11, 1587-1614. http://dx.doi.org/10.1175/1520-0442(1998)011<1587:ACOTCM>2.0.CO;2

[59] Smith, R.N.B. (1990) A Scheme for Predicting Layer Clouds and Their Water Content in a General Circulation Model. Quarterly Journal of the Royal Meteorological Society, 116, 435-460. http://dx.doi.org/10.1002/qj.49711649210

[60] Jones, R.G., Murphy, J.M. and Noguer, M. (1995) Simulation of Climate Change over Europe Using a Nested Regional-Climate Model. I: Assessment of Control Climate, including Sensitivity to Location of Lateral Boundaries. Quarterly Journal of the Royal Meteorological Society, 121, 1413-1449.

[61] Dickinson, R.E., Kennedy, P.J. and Henderson-Sellers, A. (1993) Biosphere-Atmosphere Transfer Scheme (BATS) Version 1e as Coupled to the NCAR Community Climate Model. National Center for Atmospheric Research, Climate and Global Dynamics Division.

[62] Dumenil, L. (1992) A Rainfall-Runoff Scheme for Use in the Hamburg Climate Model. In: O’Kane, J.P., Ed., Advances in Theoretical Hydrology: A Tribute to James Dooge, Elsevier, Amsterdam, 129-157. 
[63] van den Hurk, B.J., Viterbo, P., Beljaars, A.C.M. and Betts, A.K. (2000) Offline Validation of the ERA40 Surface Scheme, ECMWF, Reading. http://www.knmi.nl.sci-hub.org/publications/fulltexts/tm295.pdf

[64] Samuelsson, P., Gollvik, S. and Ullerstig, A. (2006) The Land-Surface Scheme of the Rossby Centre Regional Atmospheric Climate Model (RCA3), SMHI. http://www.smhi.se.sci-hub.org/polopoly_fs/1.1787!meteorologi_122\%5B1\%5D.pdf

[65] Essery, R.L.H., Best, M.J., Betts, R.A., Cox, P.M. and Taylor, C.M. (2003) Explicit Representation of Subgrid Heterogeneity in a GCM Land Surface Scheme. Journal of Hydrometeorology, 4, 530-543. http://dx.doi.org/10.1175/1525-7541(2003)004<0530:EROSHI>2.0.CO;2

[66] Dümenil, L. and Todini, E. (1992) A Rainfall Runoff Scheme for Use in the Hamburg Climate Model. In: O’Kane, J.P., Ed., Advances in Theoretical Hydrology: A Tribute to James Dooge, European Geophysical Society Series on Hydrological Sciences, 129-157.

[67] Pal, J.S., Giorgi, F., Bi, X., Elguindi, N., Solmon, F., Rauscher, S.A., et al. (2007) Regional Climate Modeling for the Developing World: The ICTP RegCM3 and RegCNET. Bulletin of the American Meteorological Society, 88, 13951409. http://dx.doi.org/10.1175/BAMS-88-9-1395

[68] Christensen, O.B., Drews, M., Christensen, J.H., Dethloff, K., Ketelsen, K., Hebestadt, I., et al. (2006) The HIRHAM Regional Climate Model, Version 5 ( $\beta$ ). Techical Rep., 6-17.

[69] Van Meijgaard, E., Van Ulft, L.H., Van de Berg, W.J., Bosveld, F.C., Van den Hurk, B., Lenderink, G., et al. (2008) The KNMI Regional Atmospheric Climate Model RACMO. Version 2.1, Koninklijk Nederlands Meteorologisch Instituut. http://a.knmi2.nl.sci-hub.org/knmi-library/knmipubTR/TR302.pdf

[70] Samuelsson, P., Jones, C.G., Willén, U., Ullerstig, A., Gollvik, S., Hansson, U., et al. (2011) The Rossby Centre Regional Climate Model RCA3: Model Description and Performance. Tellus A, 63, 4-23. http://dx.doi.org/10.1111/j.1600-0870.2010.00478.x

[71] Jones, R., Noguer, M., Hassell, D., Hudson, D., Wilson, S., Jenkins, G., et al. (2004) Generating High Resolution Climate Change Scenarios Using PRECIS, Ruth Taylor (Hadley Centre for Climate Prediction and Research, UK), Exeter. http://www.metoffice.gov.uk/media/pdf/6/5/PRECIS Handbook.pdf 